South African Journal for Research in Sport, Physical Education and Recreation, 2008, 30(2): 147-165.

Suid-Afrikaanse Tydskrif vir Navorsing in Sport, Liggaamlike Opvoedkunde en Ontspanning, 2008, 30(2): 147-165. ISSN: 0379-9069

\title{
INVESTIGATING SPORT CELEBRITY ENDORSEMENT AND SPORT EVENT SPONSORSHIP AS PROMOTIONAL CUES
}

\author{
Neels VAN HEERDEN, Angelique KUIPER \& Honorata M. SAAR \\ Department of Marketing and Communication Management, University of Pretoria, Pretoria, \\ Republic of South Africa
}

\begin{abstract}
When detailed product information is not available to consumers inferences are made using product cues to reduce uncertainty and to form perceptions of products. Advertisers can make use of sport sponsorship and sport celebrity endorsement as extrinsic cues to influence consumers' pre-purchase attitudes. These cues are expensive forms of advertising. Managers need to establish whether they provide a satisfactory return on investment. This study explored consumers' attitudes and the effect of sport event sponsorship and sport celebrity endorsement on key brand/manufacturer related variables such as brand quality, product uniqueness, manufacturer esteem and corporate citizenship. A total number of 201 respondents participated in the study. A non-probability sample was used. Results indicate that sport event sponsorship was perceived by participants as a product uniqueness, manufacturer esteem and corporate citizenship cue, significantly enhancing responses on product related variables. The sport celebrity endorsement cue had a significant effect on uniqueness and esteem, but did not significantly influence brand quality. Using these results managers can substantiate the use of sport event sponsorship to increase consumers' pre-purchase attitudes of product uniqueness, manufacturer esteem and corporate citizenship; and sport celebrity endorsement to increase their pre-purchase attitudes of product uniqueness and manufacturer esteem; thus positively affecting consumers' pre-purchase attitudes that may influence buyer behaviour.
\end{abstract}

Key words: Sport sponsorship; Celebrity endorsement; Brand quality; Product uniqueness; Manufacturer esteem and corporate citizenship.

\section{INTRODUCTION}

South Africans will always be passionate about sport and there is no better association for a company's brand than an association with sport (Etzman \& Penstone, 2001:14). Performances in the 2007 International Cricket Council (ICC) World Cup, the 2006 FIFA World Cup ${ }^{\mathrm{TM}}$ and the 2007 20twenty Cricket World Cup, and the 2007 Rugby World Cup in France, captures the imagination and even below-par results will not reduce this passion. Marketers can capitalise on this passion for sport for instance, by utilising sport event sponsorship and/or sport celebrity endorsement. These aspects can be very closely be monitored as promotional cues.

Cues can be classified as either intrinsic (physical product attributes) or extrinsic (intangible product attributes such as brand name, price and packaging). Richardson et al. (1994:30) are 
of the view that consumers focus highly on extrinsic cues in quality assessment. Companies should therefore incorporate extrinsic cues into their advertising.

Two widely used extrinsic cues used by marketers are event sponsorship and celebrity endorsement. However, they are expensive forms of advertising and managers have to justify the use of extrinsic cues such as event sponsorship and celebrity endorsement investments (Jowdy \& McDonald, 2002b:248) in terms of profitability and a positive return on investment.

A problem that managers face is how to measure the effectiveness of extrinsic cues. Advertising moves consumers through the following phases of the consumer decision-making process: awareness; knowledge; liking; preference; conviction and purchase) and these extrinsic cues may have an influence on the decision-making process and consumer buying behaviour (Belch \& Belch, 2001:210).

Complete product information is rarely available to consumers (Dean, 1999:2) and consumers infer information where relevant product information is absent to form an integrated, overall evaluation (Huber \& McCann, 1982:324-333). Dean (1999:2) concludes that product cues in advertising are important to consumers in making inferences, reducing uncertainty and forming product preferences. Dean (1999:2) further posits that sport event sponsorship and sport celebrity endorsement cues are designed to strongly and positively affect consumer and brand perceptions.

\section{OBJECTIVE OF THE STUDY}

The study focused on the effect of event sponsorship and celebrity endorsement on perceptions of key brand related variables, namely: brand quality; product uniqueness; manufacturer esteem; and corporate citizenship. The main objective is to establish whether event sponsorship and celebrity endorsement affect brand/manufacturer evaluation in a selected target market.

\section{LITERATURE REVIEW}

\section{Advertising and sponsorship cues}

Cue utilisation theory provides a way to assess consumer perceptions of product quality. According to this theory, products consist of an array of cues that serve as surrogate indicators of quality to shoppers (Richardson et al., 1994:29). The concept of cueing is very important in advertising because much of past experience is filed in memory as a visual element (Pettersson, 1991:2) and these experiences provide a framework of meaning that can be used to interpret messages (Moriarty, 2003:1).

Advertising, with its highly condensed message formats, uses a shortened form of information processing. Through association, the message depends upon cues to elicit the associated meanings. In other words, cueing drives the process of association (Moriarty, 2003:1).

Meenaghan (2001:95) proposed that sponsorship works differently on the consumer than does other forms of advertising and promotion in that it engages the consumer by bestowing benefit on an activity with which the consumer has an intensely emotional relationship. McDaniel 
1999:180) is of the view that it appears that consumers may indeed have memory-based expectations of advertised brand/ sport relationships.

\section{Sport event sponsorship}

Corporate sponsorship of sports and other events is one of the fastest growing forms of marketing communications used to reach target audiences. The rate of growth in sponsorship expenditures is greater than for traditional media advertising and sales promotion (Roy \& Cornwell, 2004:185).

Gardner and Shuman (1998:44) define sponsorship as an investment in an event or cause in order to support the company's corporate objectives, such as an enhancement of corporate image or an increase in brand awareness. Sponsorship offers a platform to communicate emotionally with consumers who are passionate about sport by "developing brand associations, creating brand exposure, demonstrating new products and services, and building the corporate image" (Penstone, 2001:19). Cornwell and Maignan (1998:22) also suggest that two of the most common reasons why companies enter into sponsorship arrangements, are: "(1) to increase brand awareness, and (2) to establish, strengthen, or change brand image".

In South Africa the total sponsorship spending increased from R1 986 million in 2000 to R4 066 million in 2005 (Du Plessis et al., 2005:327) growing at an average rate of 23\% per annum since 1986. Sport sponsorship attracts approximately $70 \%$ of all sponsorship expenditure in South Africa (Du Plessis et al., 2005:321). One of the problems in sport sponsorship is that it cannot accurately be measured and that it can become unfocused and difficult to track. Return on investment can be indirectly measured in TV time, media coverage and increased sales. However, there is no scientific formula that calculates exact benefits such as increase in sales or market share.

\section{Sponsorship evaluation}

Several theories have been developed to address the issue of evaluating sponsorships. One of them is the balance theory, which states that the evaluation of an object is affected by how the evaluation will fit with other related attitudes held by the consumer (Heider, in Dean, 2002:77). The theory is useful in the explanation of attitude formation and change. The balance theory is relevant to event sponsorship as it envisions a relationship between the endorser, the object and the endorsement as the three points of a triangle. The theory focuses on balance between the elements in the triad and believes that consumers will alter their perceptions in order to maintain this consistency. The disadvantage of this theory is that consumers may alter their attitude negatively in order to achieve this balance. The theory deduces that a linkage is formed between the sponsor and the event.

Osgood and Tannenbaum (1955:42-55) provide direction for attitude change and specifies degrees of positive or negative evaluation of elements. The theory posits that attitudes may be held weakly or strongly in either a favourable or unfavourable direction. The theory also postulates that the presence of incongruity may prompt attitude change toward both the other elements in the triad.

Dean (1999:4) suggests that a "halo" effect occurs when consumers believe that the sponsor's products are superior to those of competitors because of the feeling of goodwill created by the 
linkages suggested by the balance and congruity theories. The shortcomings of the above theories are that the duration of the linkages created is temporary and they must be reinforced consistently.

Poon and Prendergast (2006:471) argue that the relevance of a sponsor's product effect on consumer responses (in terms of quality perceptions, attitude towards the brand and purchase intention) should be researched.

\section{Celebrity endorsement}

Celebrity endorsement is frequently used in advertisements to enhance the effectiveness of persuasive communication. With the increasing number of global sporting events, marketing and advertising practitioners may be more willing to spend millions of dollars on employing celebrity athletes to improve their promotional strategies in an attempt to associate their product images with those athlete endorsers (Kim \& Na, 2007:310). Research has found supporting evidence that celebrity endorsements impact on audience attention, recall, evaluations and purchase intentions (Hsu \& McDonald, 2002:19). The use of sports stars might work in order to draw the attention towards an ad, but it is not successful in terms of attitudinal effects (Dudzik \& Gröppel-Klein, 2005:64).

According to Henriks (1996:130), celebrity endorsements can assist an organisation to differentiate a product or service and is also a way to build instant name recognition. Celebrity endorsement entails associating a product or service with a person whose name and face are already well known. It has been asserted that "...firms have been juxtaposing their brands and themselves with celebrity endorsers (e.g. athletes, actors) in the hope that celebrities may boost effectiveness of their marketing and/or corporate communication attempts for at least a century" (Erdogan \& Kitchen, 1998:17).

For large companies with well-established brand equity and image, the value of partnering with high profile athletes may be most effective. Jowdy and McDonald (2002a:186) state that companies have traditionally selected high profile athletes from major sports to endorse all types of products. According to Lyons and Jackson (2001:97), endorsements by AfricanAmerican superstar athletes such as Michael Jordan, Bo Jackson, Michael Johnson, and Cynthia Cooper have made Nike a household name within the African-American community. Moreover, the Nike logo appears on the jerseys, pants, and hats of thousands of professional athletes. Small firms can probably best afford celebrity endorsements by concentrating on local or regional stars.

Several studies have compared the use of a celebrity endorser versus a non-celebrity endorser. Block (as quoted by Till, 2001:36) found that the use of a celebrity as a endorser for beer led to the advertisement being evaluated as being more "interesting", "stronger" and more "effective", while the beer was evaluated as more "pleasant", "superior" and "enjoyable". Petty et al. (as quoted by Till, 2001:36) found that the use of a celebrity endorser led to higher brand evaluations than the use of average citizens as endorsers.

\section{Dependent variables}

The main presupposition of the study is that the two extrinsic cues of interest (celebrity endorsement and event sponsorship) would affect key brand/manufacturer related variables of 
perceived product quality, perceived product uniqueness, manufacturer esteem and perceived corporate social responsibility. Perceived quality and uniqueness are pivotal drivers of shopping behaviour and product choice Dean (1999:10). In his study Dean (1999:2) used these variables to simultaneously construct consumers' pre-purchase attitudes while Aaker (as quoted in Dean, 1999:2) argues that all four variables are sub-constructs under the higher level construct of customer-based brand equity and are all associated with future sales, profits and sustainable competitive advantage. Therefore marketers may be interested in developing promotion programmes that can stimulate favourable responses on these variables.

These four dependent variables were chosen for their hypothesised ability to be affected by the extrinsic cues chosen for this study, and for their relationship to consumer perceptions and behaviours of interest to the marketers.

Perceived product quality can be defined as a consumer's overall judgement of a brand's superiority in its performance in relation to another competing brand (Du Plessis \& Rousseau, 1999:148) and is the main driver for loyalty (Martensen et al., 2000:544). Gwinner and Eaton (1999:54) suggest that brand positioning goals may be partially accomplished through event sponsorship. Silvera and Austad (2004:1520) found a positive correlation between a likable endorser and a favourable attitude towards the product being endorsed.

Perceived product uniqueness can be compared to brand differentiation and can be defined as the degree to which consumers feel the product is different from a competing product (Dean, 1999:2). If customers perceive a brand to have unique benefits that satisfy their needs and wants, the product will be given a value added and will be favourable towards competitors' products (Creutz \& Senning, 2006:13). Amis et al. (1999:250) argue that sponsorship provides a significant increase to the perceived customer value of the product or service. Celebrities enhance product recall, which explains that celebrity endorsements enhance consumer perceptions of product value (Clark \& Horstmann, 2003:1).

Manufacturer esteem is defined as the degree to which the brand is held in high regard, trusted and respected by its customers relative to alternate brands in the same product category (Dean, 1999:2). The fact of associating your product with a well known individual acts to increase the positive view of the consumer (Daneshvary \& Schwer, 2000:212). Madrigal (2001:145) concludes that companies have increasingly turned to sponsorship as a marketing communications vehicle in the hope that the goodwill that consumers feel toward an event, cause, or sports team will rub off on their brands. Seno and Lukas (2007:122) state that comparatively little research has been conducted on the equity effects of celebrity product endorsement.

Perceived corporate citizenship can be referred to as corporate social responsibility, which can be defined as the responsibility a organisation has to interact with non-profit organisations, communities and other stakeholders to improve the conditions of society as a whole. Dean (2002:77) argues that it is not uncommon for businesses to sponsor events that benefit local charities and service organisations. The intent of such sponsorship is to generate goodwill and to enhance the image of the business (sponsor). Corporate citizenship therefore refers to how the organisation fulfils its perceived societal obligations and the perceived status of the organisation in respect to these obligations (Belch \& Belch, 2001:598; Marx et al., 1998:130). The argument here is that sponsors "plough back" money into those sporting 
events attended by their customers as a "token" of good-will, although altruism is probably mostly overshadowed by the marketing effects generated through involvement in sport sponsorship.

\section{RESEARCH HYPOTHESES}

South Africa is gaining status as a host country for future high profile sporting events, for instance, the, 2010 FIFA World $\mathrm{Cup}^{\mathrm{TM}}$ and not much research on this topic has been conducted specifically with a South African focus. This study focuses on the ability of extrinsic cues in print advertising to drive consumer responses on these variables.

The balance and congruity theories demonstrate the effect of event sponsorship on corporate responsibility. The "halo" effect indicates the effect of event sponsorship on consumers' perceptions of the superiority of the sponsor's product. This superiority can be described by two dependent variables under investigation in this study, namely, product uniqueness and manufacturer esteem. Based on the three theories the following hypothesis was formulated:

$\mathbf{H}_{1}$ : Consumers exposed to a sport event sponsorship claim about a brand, will show higher scores on measures of uniqueness, esteem and citizenship than consumers' not exposed to a sport event sponsorship claim for the same brand.

Based on the discussion of sport celebrity endorsement, the following hypothesis was derived:

$\mathbf{H}_{2}$ : Consumers exposed to a sport celebrity's endorsement claim about a brand, will show higher scores on measures of quality, uniqueness and esteem than consumers' not exposed to a sport celebrity's endorsement claim for the same brand.

The last hypothesis was based on $\mathrm{H}_{1}$ and $\mathrm{H}_{2}$ and states:

$\mathbf{H}_{3}$ : Sport event sponsorship has a greater effect on consumers' pre-purchase attitudes than sport celebrity endorsement.

\section{METHOD}

An adaptation of a study conducted by Dean (1999) in the United States of America was used. This research study adds value to Dean's study as it was adapted within a South African context and focused specifically on a selection of university students and sporting events and celebrities. Dean's study used popularity as a third independent variable, whereas this research takes a different approach and investigates a comparison between sport celebrity endorsement and sport event sponsorship.

The study investigated sport celebrity endorsement as an independent variable instead of third party endorsement. It also specifically investigated sport event sponsorship as an independent variable instead of event sponsorship. Dean (1999:4) hypothesised that event sponsorship would only have a positive effect on corporate citizenship. However, this study assumed that event sponsorship would influence perceptions of product uniqueness, manufacturer esteem and corporate citizenship. 


\section{Sampling}

Non-probability sampling was used to select 201 students from a large tertiary institution in Gauteng, South Africa to participate in the survey. Their use is acceptable when the dependent variables and or the intended generalisations are compatible with the population of interest and are acceptable when the subjects and target market are similar in terms of the relationship under study (Patzer, 1996: 55). Not only are students an important market segment (Ferreira \& Armstrong, 2004:197), but Corder et al. (in Laroche et al., 2004:63) stated that university students can be appropriate as they are more likely to be homogenous on certain demographic features and when they are familiar with the product, idea, or brand.

\section{Measurement}

The quantitative method used for data collection was a self-administered questionnaire with a fieldworker present to address any respondent queries. A 5-point Likert scale (with anchors strongly disagree $=1$ and strongly agree $=5$ ) was used to measure the level of attitudinal favourableness, and the scores were summated to measure the respondent's attitude (Cooper \& Schindler, 2001:234).

\section{Data collection}

The respondents were divided into three groups of 67 and each group viewed an advertisement with a different stimulus as a slogan. Stimuli were presented individually to participants containing a mock print advertisement and a questionnaire. A black and white advertisement contained an image of a sports watch and the listing of three product features commonly found in such sports watches. These were intrinsic cues and were not under investigation. Notably absent was any mention of the brand, store or sale price. The upper half of the advertisement contained one slogan (corresponding to the extrinsic cues) placed at an angle. The three subsamples of 67 respondents were each presented with a different stimulus in the advertisement attached to the questionnaire. The slogan (stimuli) stated in the advertisement was either:

1) Rated by Ernie Els as the best sports watch (Group A).

2) Proud Sponsor of the South African Olympic Team (Group B).

3) New Sports Watch (Group C).

The slogans either represented sport celebrity endorsement (Group A), sport event sponsorship (Group B), or a neutral slogan (Group C) as a testing variable. Slogan 3 represented a neutral stimulus that was used to benchmark responses. Each sub-group was exposed to different stimuli. One advertisement contained only the sport celebrity endorsement slogan, another only the sport sponsorship slogan and the third only the neutral slogan. The responses were then compared to evaluate the differences in the effect of these intrinsic cues on the variables under study that together construct the pre-purchase attitudes of respondents. The mean of each variable constructing pre-purchase attitude was calculated and the three groups were then compared to test differences in their responses. 


\section{Data analysis}

All three hypotheses that were tested compared the differences between groups. The assumption of normality was not met and the use of an independent sample t-test (MannWhitney U test) was used (Pallant, 2001:260-261).

\section{RESULTS}

\section{Importance of brand manufacturer variables}

Participants were asked to rank, in order of importance, the four brand/manufacturer variables (product uniqueness, manufacturer esteem, brand quality and corporate citizenship) constructing pre-purchase attitudes before purchasing a product. Table 1 below provides the weighted scores and the rankings of each variable.

\section{TABLE 1: RANKING OF THE FOUR BRAND/MANUFACTURER VARIABLES USING WEIGHTED SCORES}

\begin{tabular}{|l|l|l|l|c|}
\hline & $\begin{array}{l}\text { Product } \\
\text { uniqueness }\end{array}$ & $\begin{array}{l}\text { Brand } \\
\text { quality }\end{array}$ & $\begin{array}{l}\text { Manufacturer } \\
\text { esteem }\end{array}$ & $\begin{array}{l}\text { Corporate } \\
\text { citizenship }\end{array}$ \\
\hline Number of times ranked first & 28 & 148 & 17 & 8 \\
\hline Number of times ranked second & 94 & 38 & 57 & 12 \\
\hline Number of times ranked third & 58 & 9 & 104 & 30 \\
\hline Number of times ranked fourth & 21 & 6 & 23 & 151 \\
\hline Total & 531 & 730 & 470 & 279 \\
\hline Rank & 2 & 1 & 3 & 4 \\
\hline
\end{tabular}

From Table 1 it can be seen that brand quality was rated as the most important brand/manufacturer variable, followed by product uniqueness, manufacturer esteem and corporate citizenship. A speculative deduction is that corporate citizenship (social responsibility) may not be important to respondents at this stage of their life cycle, but may only become important when they are older.

\section{Reliability}

The scale measured the effect of sport event sponsorship and sport celebrity endorsement in terms of the four brand/manufacturer variables. The respondents were divided into three groups and each group viewed an advertisement with a different stimulus as a slogan. The slogans either represented sport event sponsorship, sport celebrity endorsement or a neutral slogan as a testing variable. Respondents were then asked to indicate their level or agreement with statements about the advertisement. The Likert scale used to measure pre-purchase attitudes was tested for its internal consistency reliability by calculating Cronbach's alpha. There were 12 questions and three questions were used to test each variable. In Table 2 the results of the reliability analysis are reflected. The Cronbach's alpha scores of Dean's study (1999:6) are also listed. It is beyond the scope of this paper to speculate on differences in the scores between the two studies. The decision to use a 5-point Likert scale in this study in stead of a 7-point semantic differential scale as used by Dean (1999:12), differences in sample size, and differences in the advertising cues used in the advertisement might have contributed to that. 
TABLE 2: MEASURING VARIABLES AND RELIABILITY ANALYSIS

\begin{tabular}{|c|c|c|c|c|c|}
\hline $\begin{array}{l}\text { Measuring } \\
\text { variable }\end{array}$ & Statement in questionnaire & Mean & SD & $\begin{array}{l}\text { CRONBACH } \\
\text { ALPHA } \\
\text { (this study) }\end{array}$ & $\begin{array}{l}\text { CRONBACH } \\
\text { ALPHA } \\
\text { Dean (1999) } \\
\end{array}$ \\
\hline \multirow{3}{*}{$\begin{array}{l}\text { Corporate } \\
\text { citizenship }\end{array}$} & $\begin{array}{l}\text { The company that makes the } \\
\text { advertised sports watch cares } \\
\text { about its customers. }\end{array}$ & 3.08 & 1.03 & \multirow{3}{*}{0.79} & \multirow{3}{*}{0.89} \\
\hline & $\begin{array}{l}\text { The company that makes the } \\
\text { advertised sports watch is } \\
\text { socially responsible. }\end{array}$ & 2.43 & 0.92 & & \\
\hline & $\begin{array}{l}\text { The company that makes the } \\
\text { advertised sports watch is a } \\
\text { good "corporate citizen". }\end{array}$ & 2.99 & 0.96 & & \\
\hline \multirow{3}{*}{$\begin{array}{l}\text { Manufacturer } \\
\text { Esteem }\end{array}$} & $\begin{array}{l}\text { I can trust the company that } \\
\text { makes the advertised sports } \\
\text { watch. }\end{array}$ & 3.56 & 0.92 & \multirow{3}{*}{0.76} & \multirow{3}{*}{0.83} \\
\hline & $\begin{array}{l}\text { Compared to other sports } \\
\text { watches, I hold the } \\
\text { manufacturer of the advertised } \\
\text { watch in high regard. }\end{array}$ & 2.82 & 1.10 & & \\
\hline & $\begin{array}{l}\text { The company that makes the } \\
\text { advertised sports watch does } \\
\text { not deserve my respect. ( } \mathrm{r} \text { ) }\end{array}$ & 3.13 & 0.98 & & \\
\hline \multirow{3}{*}{ Brand quality } & $\begin{array}{l}\text { Compared to other sports } \\
\text { watches, the advertised watch } \\
\text { is a superior product. }\end{array}$ & 2.56 & 1.04 & \multirow{3}{*}{0.74} & \multirow{3}{*}{0.86} \\
\hline & $\begin{array}{l}\text { The advertised sports watch is } \\
\text { the best compared to other } \\
\text { sports watches in this product } \\
\text { class. }\end{array}$ & 2.37 & 0.95 & & \\
\hline & $\begin{array}{l}\text { The advertised sports watch } \\
\text { will perform better than other } \\
\text { sports watch brands. }\end{array}$ & 2.90 & 0.98 & & \\
\hline \multirow{3}{*}{$\begin{array}{l}\text { Product } \\
\text { Uniqueness }\end{array}$} & $\begin{array}{l}\text { Compared to other sports } \\
\text { watches, the advertised watch } \\
\text { is unique. }\end{array}$ & 2.53 & 1.09 & \multirow{3}{*}{0.63} & \multirow{3}{*}{0.76} \\
\hline & $\begin{array}{l}\text { The advertised sports watch } \\
\text { "stands out" from other sports } \\
\text { watch brands. }\end{array}$ & 2.65 & 1.16 & & \\
\hline & $\begin{array}{l}\text { The advertised sports watch is } \\
\text { very similar to other sports } \\
\text { watches. (r) }\end{array}$ & 2.64 & 0.86 & & \\
\hline
\end{tabular}

$\mathrm{n}=201, \mathrm{SD}=$ standard deviation; $(\mathrm{r})=$ reverse statements 
The Cronbach reliability coefficient for three variables was above the cut-off point of 0.70 except for one variable, namely, product uniqueness. The scale could not be made more reliable because there were only three questions in this sub-dimension and none of the questions could have been deleted. Therefore it was accepted, but must be seen as a limitation.

\section{Testing of hypotheses}

Abbreviations for the sub-dimensions of dependent variables included: brand quality was referred to as TOTAL (quality); product uniqueness was referred to as TOTAL (unique); manufacturer esteem was referred to as TOTAL (esteem); corporate citizenship was referred to as TOTAL (corpc); and the respondents' pre-purchase attitudes was referred to as TOTALL. A level of significance of 0.05 was chosen for all hypotheses.

\section{Hypothesis 1}

The first hypothesis $\left(\mathrm{H}_{1}\right)$ focused on the effect that a sport event sponsorship claim, has on respondents' pre-purchase attitudes of uniqueness, esteem and citizenship. The null hypothesis is stated below:

$\mathrm{H}_{1 \text { (null) }}$ : Subjects exposed to a sport event sponsorship claim about a brand, will show no difference in scores on measures of uniqueness, esteem and citizenship to subjects not exposed to a sport event sponsorship claim for the same brand.

Hypothesis 1 was divided into three sub-hypotheses and each variable was tested separately. The two groups (B: respondents exposed to the sport event sponsorship claim and C: respondents exposed to a neutral advertising cue) were measured on the same measures of uniqueness, esteem and citizenship and the groups were compared on each of these measures separately as sub-hypotheses.

$\mathrm{H}_{1 \text { (unique) }}$ : Measured sport event sponsorship's effect on uniqueness.

$\mathrm{H}_{1 \text { (esteem) }}$ : Measured sport event sponsorship's effect on esteem.

$\mathrm{H}_{1 \text { (corp) })}$ : Measured sport event sponsorship's effect on corporate citizenship.

The hypothesis measured the differences between two groups (Group B and Group C) on the same variable (TOTALunique).

The first sub-hypothesis, $\mathrm{H}_{1 \text { (unique), }}$, tested the following:

$\mathrm{H}_{\text {1null(unique) }}$ : Subjects exposed to a sport event sponsorship claim about a brand will show no difference in scores on measures of uniqueness to subjects not exposed to a sport event sponsorship claim for the same brand.

It was assumed that an independent sample t-test should be used but it was first necessary to determine whether the underlying assumptions of an independent sample t-test were satisfied. This was done using a Kolmogorov-Smirnov test to test for normality and the results are depicted in Table 3. 


\section{TABLE 3: RESULTS OF A KOLMOGOROV-SMIRNOV TEST FOR NORMALITY CONDUCTED FOR GROUPS B AND C ON SPORT EVENT SPONSORSHIP'S EFFECT ON TOTAL(UNIQUE)}

\begin{tabular}{|l|l|l|l|l|l|l|l|}
\hline \multicolumn{2}{|c|}{} & \multicolumn{3}{c|}{ Kolmogorov-Smirnov $^{(\mathbf{a})}$} & \multicolumn{3}{c|}{ Shapiro-Wilk } \\
\hline & Group & Statistic & df & Sig. & Statistic & df & Sig. \\
\hline \multirow{2}{*}{$\begin{array}{l}\text { TOTAL } \\
\text { (unique) }\end{array}$} & Group B & 0.122 & 67 & 0.015 & 0.954 & 67 & 0.014 \\
\cline { 2 - 8 } & Group C & 0.161 & 67 & 0.000 & 0.909 & 67 & 0.000 \\
\hline \multicolumn{2}{|l|}{ a Lilliefors Significance Correction }
\end{tabular}

The p-value for the Group B sub-sample was 0.015 and for the Group C sub-sample it was 0.000. This indicated that Group B and Group C were both substantially lower than 0.05 and indicated a non-normal distribution for both groups. Therefore the Mann-Whitney U test was chosen as a non-parametric alternative.

For a Mann Whitney $U$ test the test scores are converted into ranked scores. The test then evaluates whether the mean ranks for the two groups differ significantly from each other. In Table 4 the mean rank scores of the sub-samples of Group B and Group C are given.

TABLE 4: DESCRIPTIVE STATISTICS FOR THE GROUP B AND GROUP C SUBSAMPLES INDICATING THE EFFECT OF SPORT SPONSORSHIP ON TOTAL(UNIQUE)

\begin{tabular}{|l|l|l|l|l|}
\hline & Group & n & Mean Rank & Sum of Ranks \\
\hline \multirow{3}{*}{ TOTAL (unique) } & Group B & 67 & 81.51 & 5461.50 \\
\cline { 2 - 5 } & Group C & 67 & 53.49 & 3583.50 \\
\cline { 2 - 5 } & Total & 134 & & \\
\hline
\end{tabular}

From Table 4 it can be observed that the two groups differ from each other significantly in their mean rank scores. This corresponded with the expectation formulated in $\mathrm{H}_{1 \text { (unique). }}$

Table 5 illustrates the results of the Mann-Whitney $U$ test showing the 2-tailed p-value that indicates the level of significance of the above assumptions.

TABLE 5: RESULTS OF THE MANN-WHITNEY U TEST INDICATING THE LEVEL OF SIGNIFICANCE FOR THE DIFFERENCES IN THE MEAN RANKS OF TOTAL(UNIQUE) OF GROUP B AND GROUP C

\begin{tabular}{|l|c|}
\hline & TOTAL(unique) \\
\hline Mann-Whitney U & 1305.500 \\
\hline Wilcoxon W & 3583.500 \\
\hline Z & -4.211 \\
\hline Asymp. Sig. (2-tailed) & 0.000 \\
\hline
\end{tabular}

The p-value was smaller than $0.05(\mathrm{p}<0.05)$ and therefore the null hypothesis was rejected.

It was concluded that subjects exposed to a sport event sponsorship claim about a brand showed higher scores on measures of uniqueness than subjects not exposed to a sport event sponsorship claim for the same brand. 
Similar tests were done with the other two sub-hypotheses, namely, esteem and corporate citizenship. The null hypotheses were also rejected and it was concluded that respondents exposed to a sport event sponsorship claim about a brand, showed higher scores on measures of esteem and corporate citizenship than subjects not exposed to a sport event sponsorship claim for the same brand. The null hypotheses of all three sub-dimensions of $\mathrm{H}_{1}$ were rejected and respondents exposed to a sport event sponsorship claim about a brand showed higher scores on measures of uniqueness, esteem and corporate citizenship than respondents not exposed to a sport event sponsorship claim for the same brand. Dean (1999:10) found that a sponsorship cue had little effect on product quality and uniqueness effects but a marked effect on perceived corporate citizenship.

The results of the two studies may imply that advertisers can make use of sport event sponsorship to increase students' pre-purchase attitudes of manufacturer esteem and corporate citizenship. These two variables were ranked lowest in Table 1.

\section{Hypothesis 2}

The second hypothesis $\left(\mathrm{H}_{2}\right)$ focused on the effect that a sport celebrity endorsement claim has on respondents' pre-purchase attitudes of brand quality, uniqueness and esteem. The null hypothesis is:

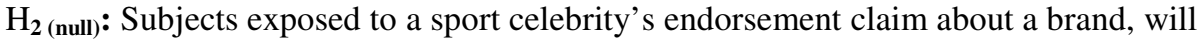
show no difference on measures of brand quality, uniqueness and esteem to subjects not exposed to a sport celebrity's endorsement claim for the same brand.

Hypothesis two was divided into three sub-hypotheses and each variable was tested separately. The two groups (Group A: respondents exposed to the sport celebrity endorsement claim) and Group C: respondents exposed to a neutral advertising cue) were measured on the same measures of brand quality, uniqueness and esteem and the groups were compared on each of these measures separately as sub-hypotheses.

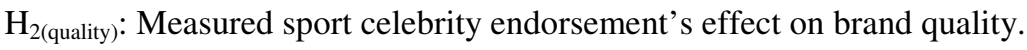

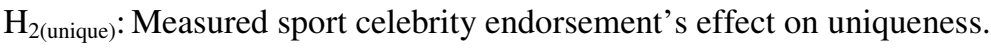

$\mathrm{H}_{2(\text { esteem) }}$ : Measured sport celebrity endorsement's effect on esteem.

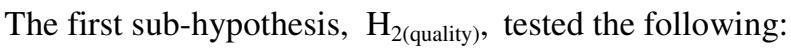

$\mathrm{H}_{2(\text { quality): }}$ : Subjects exposed to a sport celebrity's endorsement claim about a brand, will show higher scores on measures of quality than subjects not exposed to a sport celebrity's endorsement claim for the same brand.

A Kolmogorov-Smirnov test was conducted, as in $\mathrm{H}_{1}$, to test for normality, and the results are shown in Table 6. 
TABLE 6: RESULTS OF A KOLMOGOROV-SMIRNOV TEST FOR NORMALITY CONDUCTED FOR GROUPS A AND C ON SPORT CELEBRITY ENDORSEMENT'S EFFECT ON TOTAL(QUALITY)

\begin{tabular}{|l|l|l|l|l|l|l|l|}
\hline \multicolumn{2}{|c|}{} & \multicolumn{3}{c|}{ Kolmogorov-Smirnov ${ }^{(\mathbf{a})}$} & \multicolumn{3}{c|}{ Shapiro-Wilk } \\
\hline & Group & Statistic & df & Sig. & Statistic & df & Sig. \\
\hline \multirow{2}{*}{ TOTAL (quality) } & Group A & 0.128 & 67 & 0.009 & 0.969 & 67 & 0.087 \\
\cline { 2 - 7 } & Group C & 0.169 & 67 & 0.000 & 0.951 & 67 & 0.010 \\
\hline
\end{tabular}

The p-value again indicated a non-normal distribution for both groups and the Mann-Whitney $\mathrm{U}$ test was used. The mean ranks of the two groups were first determined. The results are depicted in Table 7.

TABLE 7: DESCRIPTIVE STATISTICS FOR THE GROUP A AND GROUP C SUBSAMPLES INDICATING THE EFFECT OF SPORT CELEBRITY ENDORSEMENT ON TOTAL(QUALITY)

\begin{tabular}{|l|l|l|l|l|}
\hline & Group & n & Mean Rank & Sum of Ranks \\
\hline \multirow{3}{*}{ TOTAL (quality) } & Group A & 67 & 72.31 & 4845.00 \\
\cline { 2 - 5 } & Group C & 67 & 62.69 & 4200.00 \\
\cline { 2 - 5 } & Total & 134 & & \\
\hline
\end{tabular}

The above table indicates that Group A and Group $\mathrm{C}$ differ from each other in their mean rank

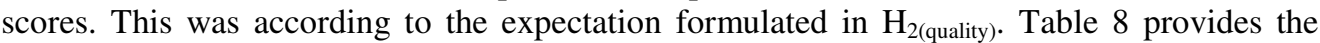
results of the Mann-Whitney U test conducted.

TABLE 8: RESULTS OF THE MANN-WHITNEY U TEST INDICATING THE LEVEL OF SIGNIFICANCE FOR THE DIFFERENCES IN THE MEAN RANK SCORES OF TOTAL(QUALITY) OF GROUP A AND GROUP C

\begin{tabular}{|l|l|}
\hline & TOTAL(quality) \\
\hline Mann-Whitney U & 1922.000 \\
\hline Wilcoxon W & 4200.000 \\
\hline Z & -1.449 \\
\hline Asymp. Sig. (2-tailed) & 0.147 \\
\hline
\end{tabular}

The two-tailed p-value of 0.147 was converted to an appropriate one tailed p-value of 0.074 . Since this value was larger than 0.05 the null hypothesis could not be rejected.

It was concluded that respondents exposed to a sport celebrity's endorsement claim about a brand showed no difference in scores on measures of quality to subjects not exposed to a sport celebrity's endorsement claim for the same brand. Similar tests were undertaken with the other two sub-hypotheses, namely, uniqueness and esteem. The p-value (one tailed) of 0.001 with respect to the variable uniqueness was smaller than 0.05 and the null hypothesis could not be accepted. With regard to the esteem variable the p-value was smaller than 0.05 and the null hypothesis could not be accepted. 
The null hypothesis of the sub-dimensions of uniqueness and esteem of $\mathrm{H}_{2}$ was rejected and the null hypothesis of the sub-dimension of quality was accepted. Therefore, it was concluded that Hypothesis 2 is partially true. It can be deduced that respondents exposed to a sport celebrity endorsement claim about a brand showed higher scores on measures of uniqueness and manufacturer esteem than subjects not exposed to a sport celebrity endorsement claim for the same brand. However, subjects exposed to a sport celebrity endorsement claim about a brand showed no difference on measures of brand quality than subjects not exposed to a sport celebrity endorsement claim for the same brand.

Dean (1999:10) found that third part endorsement may be the most managerially useful in terms of purchase intent as "endorsement was the only cue resulting in significantly elevated responses on perceived quality and uniqueness - both pivotal drivers of shopping behaviour and product choice".

From our study we conclude that only product uniqueness and not product quality was positively affected by a celebrity endorsement cue. Thus advertisers can use sport celebrity endorsement to increase respondents' pre-purchase attitudes of product uniqueness and manufacturer esteem but sport celebrity endorsement might not affect consumers' perceptions on brand quality.

\section{Hypothesis 3}

The third hypothesis $\left(\mathrm{H}_{3}\right)$ focused on the differences between the effects of sport event sponsorship and sport celebrity endorsement on respondents' pre-purchase attitudes. The null hypothesis stated:

$\mathrm{H}_{3 \text { (null): }}$ There is no difference in the effect of event sponsorship and celebrity endorsement on respondents' pre-purchase attitudes.

Two groups (Group A and B) were measured on the averages of the four brand/manufacturer variables, namely, TOTAL (quality), TOTAL (unique), TOTAL (esteem) and TOTAL (corpc) to form an overall average labelled TOTALL.

Prior to the use of an independent sample t-test it was first necessary to determine whether the underlying assumptions of an independent sample t-test were satisfied. This was done using a Kolmogorov-Smirnov test to test for normality and the results are shown in Table 9.

\section{TABLE 9: RESULTS OF A KOLMOGOROV-SMIRNOV TEST FOR NORMALITY CONDUCTED FOR GROUPS A AND B ON SPORT CELEBRITY ENDORSEMENT'S AND SPORT EVENT SPONSORSHIP'S EFFECT ON TOTALL}

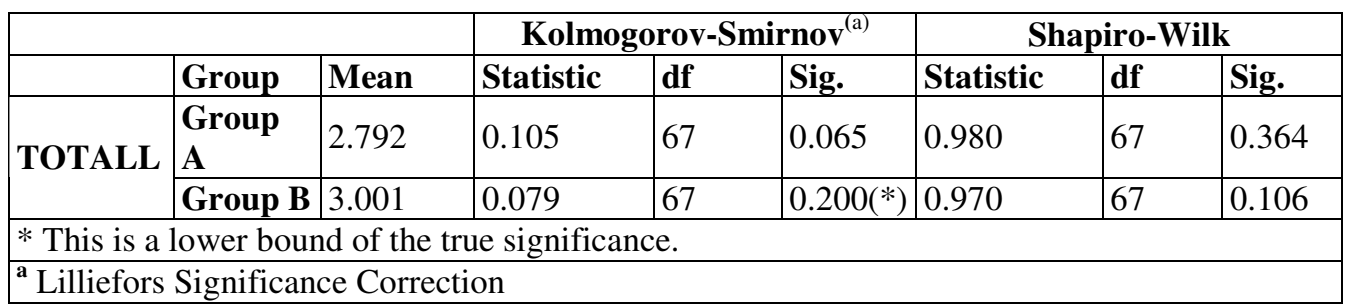


The p-value for Group A sub-sample was 0.065 and for Group B sub-sample it was 0.200 which indicated that both groups had a normal distribution ( $\mathrm{p}$-values $<0.05)$. The mean of Group A was 2.792 compared to Group B's mean of 3.001 and was in accordance with the expectation of the formulation of $\mathrm{H}_{3}$. An independent samples t-test is based on two assumptions: the assumption of normality and the assumption of equality of variances. The assumption of normality was shown in Table 9 and the Levene's test for equality of variances is shown in Table 10.

\section{TABLE 10: RESULTS OF THE LEVENE'S TEST FOR EQUALITY OF VARIANCES AND AN INDEPENDENT SAMPLES T-TEST FOR DIFFERENCES IN THE MEAN SCORES OF THE SUB-SAMPLES, GROUP A AND GROUP B, ON THE TOTALL PRE-PURCHASE ATTITUDE SCALE.}

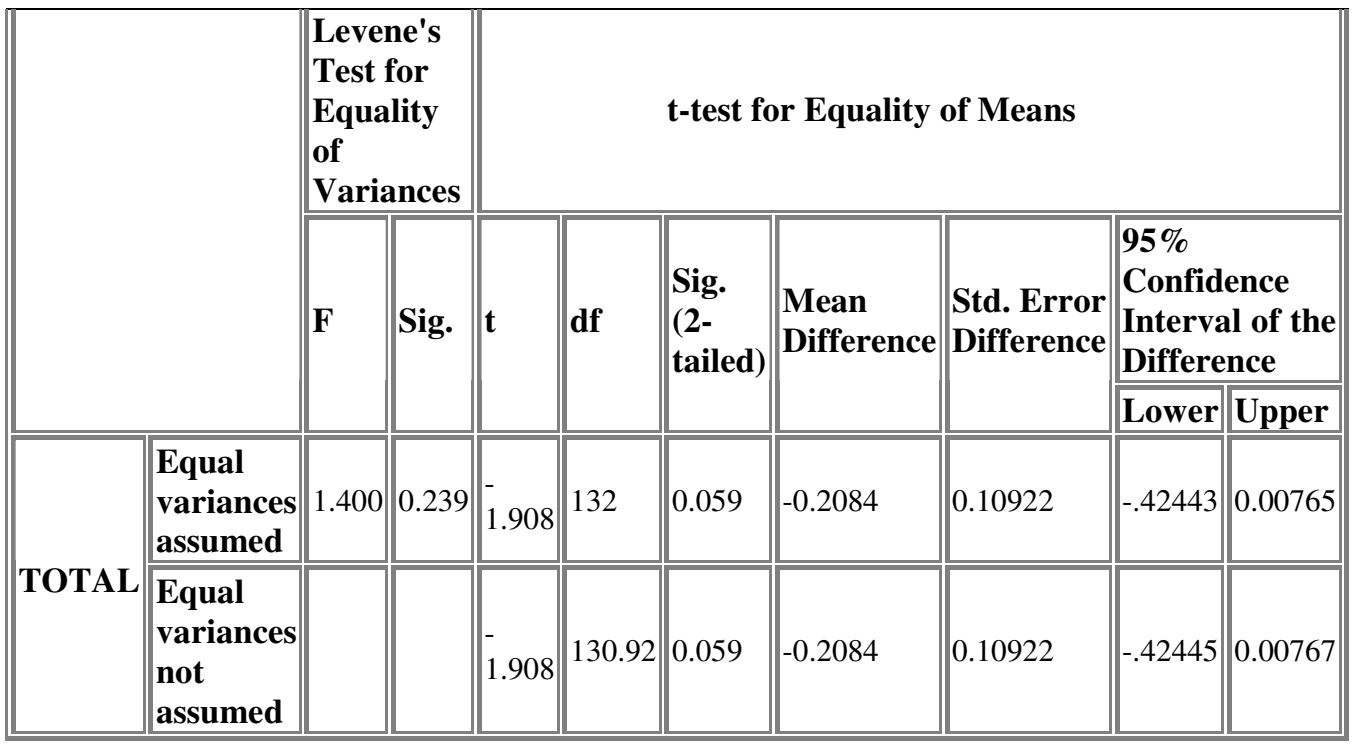

It can be observed from Table 10 that the p-value of the Levene's test for equality of variances was 0.239 and the null hypothesis of equal variances can be accepted ( $p>0.05)$. Therefore, it was concluded that the variance of the TOTALL variable in Group A (respondents exposed to the sport celebrity endorsement claim) was the same as the variance of the TOTALL variable in Group B (respondents exposed to the sport event sponsorship claim). It was necessary to look at the results of the t-test assuming equal variances. The p-value of the t-test was 0.59 . This was given as a two-tailed p-value that needed to be changed to a one-tailed p-value to reflect the directional hypothesis being tested. Since this value $(0.03)$ was smaller than 0.05 the null hypothesis was rejected. Table 9 shows that the mean of Group B was higher than Group A, which was in accordance with the stated alternative hypothesis.

It can be concluded that sport event sponsorship had a greater effect on respondents' prepurchase attitudes than sport celebrity endorsement. Thus advertisers should rather make use of sport event sponsorships to affect consumers' pre-purchase attitudes than sport celebrity endorsement. This finding may seem to contradict Dean's (1999) conclusion but the latter did not directly compare two respondent groups (A and B) on the two cues (celebrity endorsement 
and event sponsorship) as we did. Further analysis is therefore needed and a combination of the methods followed in the two studies may be required.

\section{LIMITATIONS}

A convenience sample (non-probability sample) was used and according to Cooper and Schindler (2001:192) this was the least reliable design, which could have increased the chance for sampling error. The target population could have included other non-student groupings. The Cronbach alpha reliability coefficient for the uniqueness sub-dimension was 0.63 and was less than the recommended benchmark of 0.7 used to indicate acceptable internal consistency reliability. However, the scale could not have been made more reliable because there were only three statements in this sub-dimension and none of the questions could have been deleted to improve reliability. Therefore, it was accepted as a limitation of the study. Only three statements were used per variable in the Likert scale that tested the influence of sport event sponsorship and sport celebrity endorsement on the four brand/ manufacturer variables. The study may have been more accurate if more statements were used per variable to test prepurchase attitudes.

\section{CONCLUSIONS AND RECOMMENDATIONS}

The study found that sport event sponsorship was perceived by respondents as a uniqueness, esteem and corporate citizenship cue; significantly enhancing responses on product related variables. The sport celebrity endorsement cue had a significant effect on uniqueness and esteem, but it did not significantly affect brand quality, although experimental conditions may have been inappropriate for the cue to manifest its action. Ernie Els might not have been a good choice and further testing is required on which sport celebrities are regarded as role models.

The study also found that sport event sponsorship is a more effective cue than sport celebrity endorsement when influencing consumers' pre-purchase attitudes and is a more viable option to invest in. It was deduced that respondents exposed to a sport celebrity endorsement claim about a brand showed higher scores on measures of uniqueness and esteem than subjects not exposed to a sport celebrity endorsement claim for the same brand. However, subjects exposed to a sport celebrity endorsement claim about a brand showed no difference on measures of brand quality than respondents not exposed to a sport celebrity endorsement claim for the same brand. Thus advertisers can use sport celebrity endorsement to increase respondents' pre-purchase attitudes of uniqueness and esteem, but sport celebrity endorsement will not affect consumers' perceptions on brand quality.

It was concluded that sport event sponsorship had a greater effect on respondents' prepurchase attitudes than sport celebrity endorsement. Thus advertisers should rather make use of sport event sponsorships to affect consumers' pre-purchase attitudes than sport celebrity endorsement.

An opportunity exists to measure the degree of the effect of sport event sponsorship and sport celebrity endorsement on the four brand/manufacturer variables. 


\section{CONCLUDING REMARKS}

Uniqueness, esteem and corporate citizenship are all sub-constructs under the higher level construct of customer-based brand equity and are all associated with future sales, profits and sustainable competitive advantage. Therefore, by using the results of this study, managers can substantiate the use of sport event sponsorship to increase consumers' attitudes of uniqueness, esteem and corporate citizenship and sport celebrity endorsement to increase consumers' attitudes of uniqueness and esteem: thus positively affecting their pre-purchase attitudes that may influence buyer behaviour.

\section{REFERENCES}

AMIS, J.; SLACK, T. \& BERRETT, T. (1999). Sport sponsorship as distinctive competence. European Journal of Marketing, 33(3/4):250-272.

BELCH, G.E. \& BELCH, M.A. (2001). Advertising and promotion: An integrated marketing communications perspective ( $5^{\text {th }}$ ed.). New York, NY: McGraw-Hill.

CLARK, C.R. \& HORSTMANN, I.J. (2003). Celebrity endorsements. Unpublished manuscript [http://www.rotman.utoronto.ca/ihorstmann/JEMS.2005-07-07.clark.pdf]. Downloaded on 18 August 2008.

CREUTZ, C. \& SENNING, L. (2006). Social responsible sponsorship - an easy way to a stronger brand? - a study of consumer based brand equity and consumer packaged food, international marketing \& brand management. Unpublished Master thesis. Lund, Sweden: School of Economic and Management, Lund University.

COOPER, D.R. \& SCHINDLER, P.S. (2001). Business research methods $\left(7^{\text {th }}\right.$ ed.). New York, NY: McGraw-Hill Irwin.

CORNWELL, T.B. \& MAIGNAN, I. (1998). An international review of sponsorship research. International Journal of Advertising, 27(1): 1-22.

DANESHVARY, R. \& SCHWER, R.K. (2000). The association endorsement and consumers' intention to purchase. Journal of Consumer Marketing, 17(3): 203-213.

DEAN, D.H. (1999). Brand endorsement, popularity, and event sponsorship as advertising cues affecting consumer pre-purchase attitudes. Journal of Advertising, 28(3): 1-12.

DEAN, D.H. (2002). Associating the corporation with a charitable event through sponsorship: measuring the effects on corporate community relations. Journal of Advertising, 31(4): 77.

DUDZIK, T. \& GRÖPPEL-KLEIN, A. (2005). The efficiency of integrated sponsorship advertising. International Journal of Sports Marketing \& Sponsorship. October: 7(1): 57-67.

DU PLESSIS, P.J. \& ROUSSEAU, G.G. 1999. Buyer behaviour. A multi cultural approach. Halfway House, Johannesburg: Sigma.

DU PLESSIS, F.; BOTHMA, N.; JORDAAN, Y. \& VAN HEERDEN, N. (2005). Integrated marketing communication ( $2^{\text {nd }}$ ed.). Claremont, Cape Town: New Africa Books.

ERDOGAN, B.Z. \& KITCHEN, P.J. (1998). How to get the most out of celebrity endorsers. Admap, 33(4): 17-22.

ETZMAN, L. \& PENSTONE, K. (2001). More than a game. Marketing Mix, 19 (November/December): 14-17.

FERREIRA, M. \& ARMSTRONG, K.L. (2004). An exploratory examination of attributes influencing students' decisions to attend college sport events. Sport Marketing Quarterly, 13: 194-208.

GARDNER, M.P. \& SHUMAN, P. (1988). Sponsorships and small businesses. Journal of Small Business Management, 26(4): 44-52. 
GWINNER, K.P. \& EATON, J. (1999). Building brand image through event sponsorship: The role of image transfer. Journal of Advertising, 28(4), Winter: 47-57.

HENRIKS, M. (1996). Star search: here's how even the smallest business can win big-name celebrity endorsements. Entrepreneur, 24(9): 130-136.

HSU, C-K. \& McDONALD, D. (2002). An examination on multiple celebrity endorsers in advertising. Journal of Product \& Brand Management, 11(1): 19-29.

HUBER, J. \& McCANN, J. (1982). The importance of inferential beliefs on product evaluation. Journal of Marketing Research, 19(August): 324-333.

JOWDY, E. \& McDONALD, M. (2002a). Celebrity endorsers and image matching. Sport Marketing Quarterly, 11(3): 186-189.

JOWDY, E. \& McDONALD, M. (2002b). The FUTURES golf tour case study: Sponsorship sales and eduselling. Sport Marketing Quarterly, 11(4): 248-250.

KIM, Y-J. \& NA, J-H. (2007). Effects of celebrity athlete endorsement on attitude towards the product: the role of credibility, attractiveness and the concept of congruence. International Journal of Sports Marketing \& Sponsorship, 8(4): 310-320.

LAROCHE, M.; UELTSCHY, L.C.; ABE, S.; CLEVELAND, M. \& YANNOPOULOS, P.P. (2004). Service quality perceptions and customer satisfaction: evaluating the role of culture. Journal of International Marketing, 12(3): 58-85.

LYONS, R. \& JACKSON, E.N. (2001). Factors that influence African-American Gen-Xers to purchase Nikes. Sport Marketing Quarterly, 10(2): 96-97.

MADRIGAL, R. (2001). Social identity effects in a belief-attitude-intentions hierarchy: Implications for corporate sponsorship. Psychology and Marketing, 18(2): 145-165.

MARTENSEN, A.; GRONHOLDT, L. \& KRISTENSEN, K. (2000). The drivers of customer satisfaction and loyalty: cross-industry findings from Denmark. Total Quality Management, 11(4): 544-553, July.

MARX, S.; VAN ROOYEN, D.C.; BOSCH, J.K. \& REYNDERS, H.J.J. (1998). Business Management $\left(2^{\text {nd }}\right.$ ed.). Pretoria: JL van Schaik.

McDANIEL, S.R. (1999). An investigation of match-up effects in sport sponsorship advertising: The implications of consumer advertising schemas. Psychology \& Marketing, 16(2): 163-184.

MEENAGHAN, T. (2001). Understanding sponsorship effects. Psychology \& Marketing, 18(2): 95-122.

MORIARTY, S. (2003). An interpretive study of visual cues in advertising [www documents] [URL: http://spot.colorado.edu/ moriarts/viscueing.html]. Downloaded 18 August 2008.

OSGOOD, C.E. \& TANNENBAUM, P.H. (1955). The principle of congruity in the prediction of attitude change. Psychological Review, 62: 42-55.

PATZER, G. (1996). Experiment-research methodology in marketing: types and applications. Westport, London: Quorum Books.

PALLANT, J. (2001). SPSS survival manual: A step-by-step guide to data anlysis with SPSS for Windows (Version10). London: Buckingham Open University Press.

PENSTONE, K. (2001). Going for gold. Marketing Mix, 19 (November/December): 18-19.

PETTERSSON, R. (1991). Image functions. Visual Literacy Review, 20 (February): 2-3.

POON, D.T.Y. \& PRENDERGAST, G. (2006). A new framework for evaluating sponsorship opportunities. International Journal of Advertising, 25(4): 471-488.

RICHARDSON, P.S.; DICK, A.S. \& JAIN, A.K. (1994). Extrinsic and intrinsic cue effects on perceptions of store brand quality. Journal of Marketing, 58: 28-36.

ROY, D.P. \& CORNWELL, T.B. (2004). Effects of consumer knowledge on responses to event sponsorships. Psychology \& Marketing, 21(3): 185-207. 
SENO, D. \& LUKAS, B.A. (2007). The equity effect of product endorsement by celebrities: A conceptual framework from a co-branding perspective. European Journal of Marketing, 41(1/2): 121-134.

SILVERA, D.H. \& AUSTAD, B. (2004). Factors predicting the effectiveness of celebrity endorsement advertisements. European Journal of Marketing, 38(11/12): 1509-1526.

TILL, B.D. (2001). Managing athlete endorser image: The effect of endorsed product. Sport Marketing Quarterly, 10(1): 35-41.

Prof. CH van Heerden: Department of Marketing and Communication Management, University of Pretoria, Pretoria 2000, Republic of South Africa. Tel.: +27 (0)12-420-31451; Fax: 0866381545, E-mail: neels.vanheerden@up.ac.za.

\section{(Subject editor: Prof. C. Singh)}

Example of mock advertisement with the neutral, sport celebrity endorsement and sport sponsorship slogans

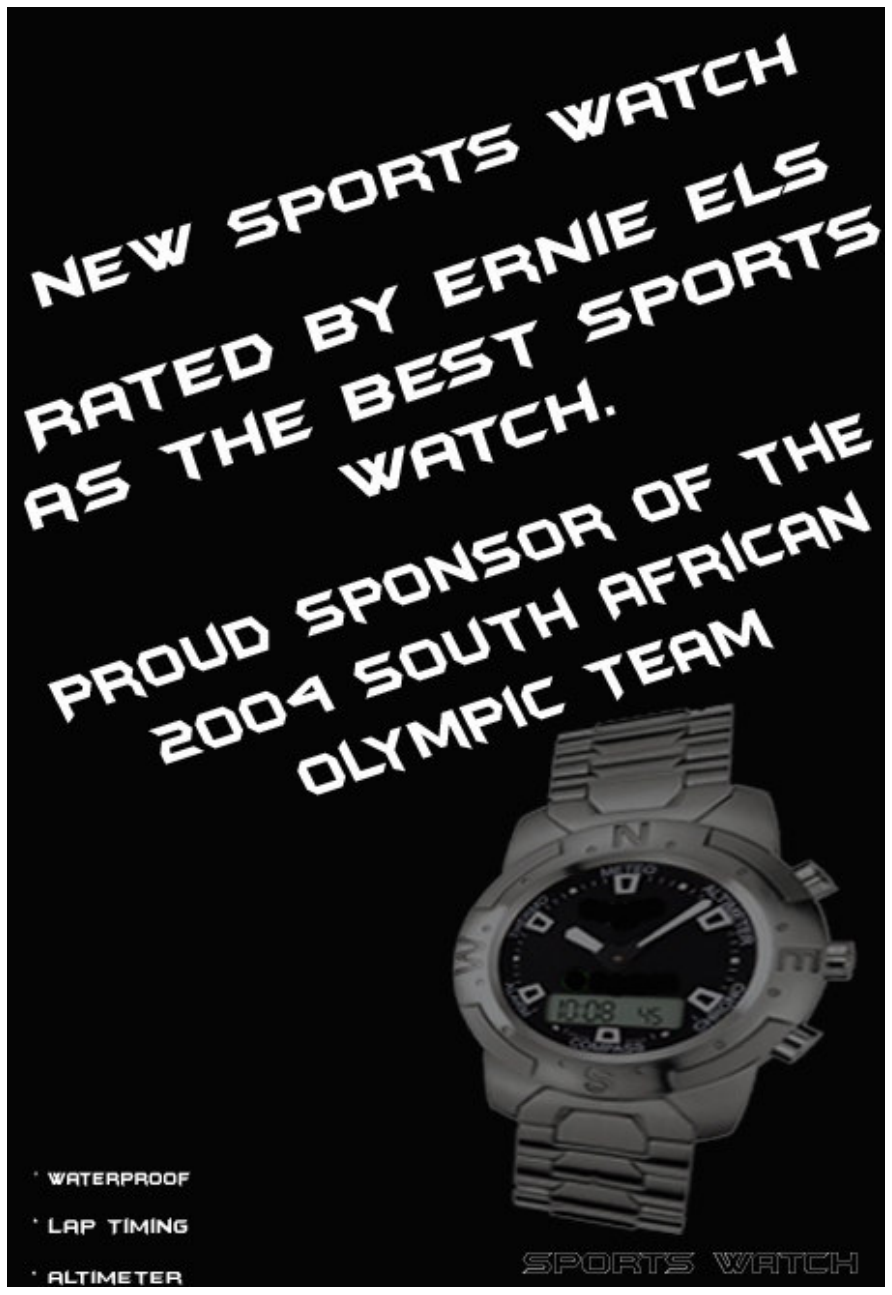

